\title{
Speaking in Pictures: Reading, Memory and Interpretation in Francesco da Barberino's Advice to Women in his Reggimento e costumi di donna
}

\section{Catherine Harding}

Volume 36, numéro 1, 2011

URI : https://id.erudit.org/iderudit/1066750ar

DOI : https://doi.org/10.7202/1066750ar

Aller au sommaire du numéro

\section{Éditeur(s)}

UAAC-AAUC (University Art Association of Canada | Association d'art des universités du Canada)

\section{ISSN}

0315-9906 (imprimé)

1918-4778 (numérique)

Découvrir la revue

\section{Citer cet article}

Harding, C. (2011). Speaking in Pictures: Reading, Memory and Interpretation in Francesco da Barberino's Advice to Women in his Reggimento e costumi di donna. RACAR : Revue d'art canadienne / Canadian Art Review, 36(1), 29-40. https://doi.org/10.7202/1066750ar
Résumé de l'article

Cet article étudie les différentes façons dont la lecture, la visualisation et l'interprétation travaillent de pair dans la tradition manuscrite de Reggimento e costumi di donna, un précis de bonne conduite rédigé par Francesco da Barberino à l'intention des femmes. Le public de la fin du Moyen-Âge était capable de naviguer entre des images verbales et visuelles du bon et du mauvais comportement selon une expérience corporelle de la lecture, alors que les lecteurs éprouvaient leur adhésion aux objectifs moraux prônés par la pensée chrétienne. Ce texte pouvait s'adresser à des hommes, des femmes et des enfants se trouvant dans un contexte familial. Le livre se termine par l'invocation d'un splendide joyau qui fonctionne comme un puissant procédé mnémotechnique destiné à aider le lecteur à se souvenir du texte et à activer le message dans son esprit.
Tous droits réservés ( $)$ UAAC-AAUC (University Art Association of Canada | Association d'art des universités du Canada), 2011
Ce document est protégé par la loi sur le droit d'auteur. L'utilisation des services d'Érudit (y compris la reproduction) est assujettie à sa politique d'utilisation que vous pouvez consulter en ligne.

https://apropos.erudit.org/fr/usagers/politique-dutilisation/ 


\title{
Speaking in Pictures: Reading, Memory and Interpretation in Francesco da Barberino's Advice to Women in his Reggimento e costumi di donna
}

\author{
Catherine Harding, University of Victoria
}

Résumé

Cet article étudie les différentes façons dont la lecture, la visualisation et l'interprétation travaillent de pair dans la tradition manuscrite de Reggimento e costumi di donna, un précis de bonne conduite rédigé par Francesco da Barberino à l'intention des femmes. Le public de la fin du Moyen-Âge était capable de naviguer entre des images verbales et visuelles du bon et du mauvais comportement selon une expérience corporelle de la lecture, alors que les lecteurs éprouvaient leur adhésion aux objectifs moraux prônés par la pensée chrétienne. Ce texte pouvait s'adresser à des hommes, des femmes et des enfants se trouvant dans un contexte familial. Le livre se termine par l'invocation d'un splendide joyau qui fonctionne comme un puissant procédé mnémotechnique destiné à aider le lecteur à se souvenir du texte et à activer le message dans son esprit.

$\mathrm{F}$ judge, is best known for two literary works that define desirable codes of conduct for men and women. He was highly regarded in the fourteenth century for his exemplary standards of morality, so much so that he was accorded the honour of a grave in the church of Santa Croce, Florence, where many Florentine worthies had been buried over the course of the centuries. ${ }^{1} \mathrm{His}$ writings belong to a broad cultural movement that had its origins in classical times but developed substantially in the Middle Ages, resulting in the creation of a group of didactic, vernacular texts containing the rules for good living. ${ }^{2}$ Roberta Krueger defines the functions of these writings accordingly: "[C]onduct books played a major role in the spread of literacy, in cultural education, and social mobility." 3 Most of the conduct manuals were not illustrated, so it is noteworthy that, almost from the very outset of the project, Francesco da Barberino chose to express his ideas using a complex interplay between text and image. He clearly believed in the close relationship between verbal and visual imagery in shaping the mind's eye. He designed a set of vivid personified images to enliven his writings, although only one of the texts, the Documenti d'amore, ever received its intended illustrations; the manuscript of the Reggimento e costumi di donna (hereafter Reggimento) includes blank spaces in relation to the text but was left unadorned (fig. 1). As the recent scholarship by Karl Enenkel and Walter S. Melion indicates, Francesco belonged to the new groups of citizens in the later Middle Ages and early modern period who contributed to meditative theory, practice, and literary creation as they transformed formerly monastic practices of meditation and hermeneutics associated with reading scripture and other texts. ${ }^{4}$ This study addresses Francesco's contribution to the genre of conduct literature, examining how he viewed the interplay between text and image as a way to create vivid, memorable texts for his readers that would be enjoyable to read, designed as they were to be retained and subjected to interpretation. 5 Writers like Francesco increasingly visualized examples of good and bad conduct, against which readers might measure their adherence to specific moral dilemmas. ${ }^{6}$
As Mary Carruthers and other scholars make clear, late medieval authors believed that certain ways of reading could lead to ethical transformation: there was a consensus that the soul could be moved as a result of the encounter with texts and images. Like Dante and Chaucer (to name some better known exemplars of this kind of writer), Francesco wanted to address an important dilemma faced by readers: namely, how to negotiate the slippery nature of the different levels of reality (moral and spiritual) lying behind the mundane world of appearances. ${ }^{7}$ As Enenkel and Melion emphasize, ideas about reading held by Dante, Chaucer, Francesco, and other contemporary writers were shaped by their overarching belief in a cosmographical model that saw signs of a divinely ordained universe imprinted throughout the levels of creation: it was imperative that men and women understood how to "read" the universe in terms of moral decisions. ${ }^{8}$ Scholars of Trecento Italian literary culture in general, and Dante scholars in particular, note how Dante and others understood the value of the act of dynamic reading, using vivid "active pictures" (imagines agentes) to heighten the reader's understanding of the interplay between ethics and ver$\mathrm{bal} / \mathrm{visual}$ image formation within the corporeal experience of reading. This study suggests that Francesco's writings need to be analyzed in relation to how he understood acts of reading, cognition, and comprehension. My article demonstrates that the Reggimento concludes with a potent image of the author/ideal reader contemplating a structured mnemonic "jewel" designed to activate the remembrance of reading different parts of the book, as well as to underscore the necessity of operating on the text as a way of self-investigation and spiritual transformation. ${ }^{9}$

This study is located within important new developments in pre-modern literacy studies. Scholars in the field are concentrating their attention on the complexities of the reading process. They note that, in the pre-modern era, reading and writing were seen to represent essential epistemological tools for spiritual, political, religious, and philosophical quests, a phenomenon that we can see in Francesco's writings, which postulate an unfolding journey of knowledge through the experience of the text. New developments in literacy studies remind us that the 


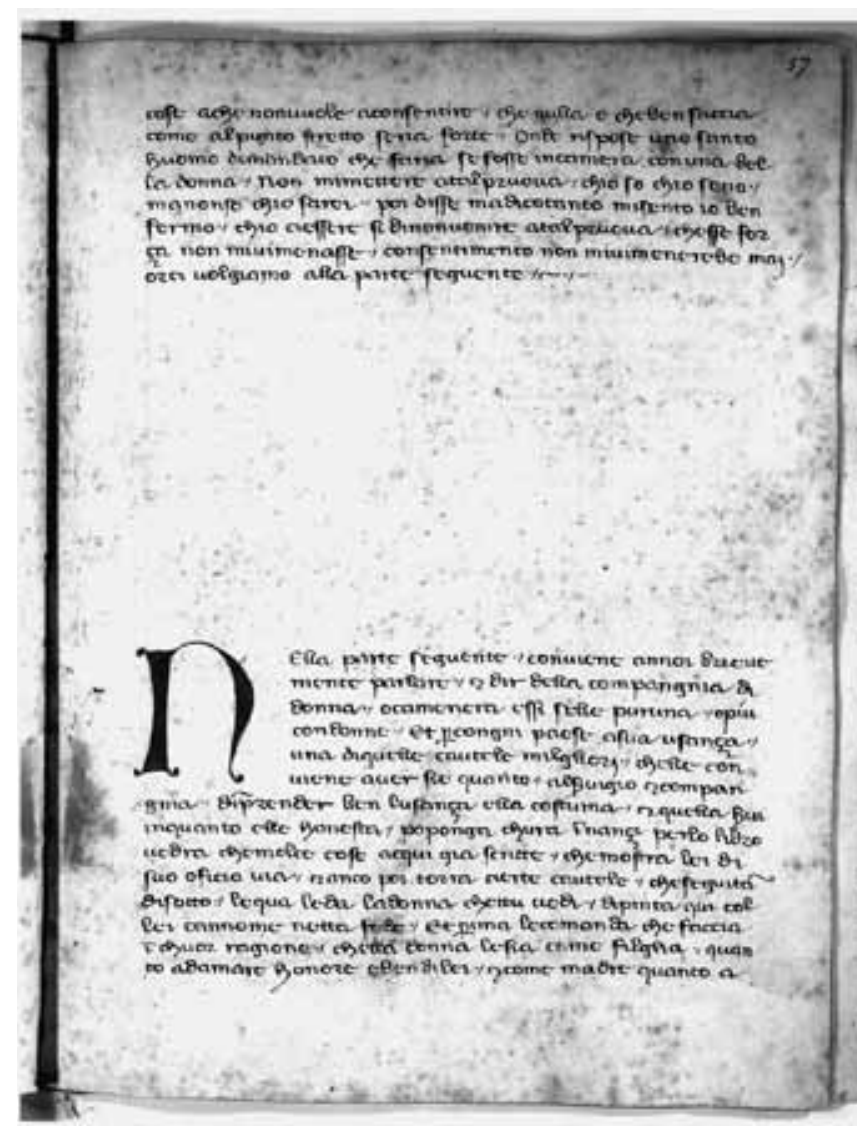

Figure I. Francesco da Barberino, Reggimento e costume di donna, Biblioteca Apostolica Vaticana, Barb. lat. 440I, f. 57r. Reproduced with permission.

processes of reading and writing were shaped by a reader's bodily experience of the text through a sensory veil that would be anchored by images, real or virtual, images that were inherently pictorial in form and effect. ${ }^{10}$ Francesco's writings therefore help us to understand another key issue in literacy studies, one often overlooked by scholars but which has great relevance, given that this book is written purportedly for women (I argue below for a wider readership than previously believed). I contend that we must grapple with how a writer's or reader's gendered identity colours the experience of text and image. ${ }^{11}$ I explore how experiencing the text of his conduct book for women, the Reggimento, might have worked to shape shifting notions of gender, based on the assumption that identity for a writer or a reader was unstable and in a constant process of formation. Scholars such as Felicity Riddy or Jocelyn Wogan-Browne remind us that men and women inhabit multiple reading positions. ${ }^{12}$ To fully understand the art of memory and how mnemonics impact on embodied readers in this period, we must consider how gender operated in the case of Francesco's texts.
I want to highlight how these texts rely on the manipulation of verbal imagery to invoke sensory experience in a gendered body, as a vital part of a multi-levelled interpretative process. Francesco deliberately chose to heighten the impact of the reader's journey through the text by evoking sensory data from the world of experience to make the engagement with the words more meaningful. ${ }^{13} \mathrm{He}$ wrote, as a male author, for men and women, especially for individuals within a familial context; however, as I argue here, there might well have been a good deal of slippage in terms of gender identity and reading across multiple-gendered audiences. To understand his contribution, we should examine his two main authorial projects.

Francesco's work for men, the Documenti d'amore, is a handbook of good manners begun in Italy before 1309 and finished in Provence around $1313 . .^{14} \mathrm{He}$ adopted a complicated textual structure for this book, with poetry written in the vernacular, or volgare, which was accompanied by a Latin prose paraphrase, and finally completed by an adjacent detailed Latin gloss. Not surprisingly given his legal training, the page layout resembles Bolognese legal manuscripts done in the manner known as textus inclusus, in which texts on each page are nested within each other and share a sense of interplay as they are read. ${ }^{15}$ In the case of the Documenti manuscript, the page layout features a central image with vernacular poetry, a wrapping of the poem by a Latin paraphrase, and finally the gloss, so that the commentary extends across two columns of the full page. ${ }^{16}$

The Documenti manuscripts include illustrations of his various allegorical ideas, which Francesco designed himself. Current scholarship rejects the previously held notion that the illustrations were done by his hand: he is now assigned a supervisory role in the creation of the imagery, while the identity of the artists who worked on the manuscripts is much debated. ${ }^{17}$ Each of the chapters starts with a personified allegorical image (such as Hope or Prudence) functioning as a pictorial heading to the chapter. There are occasional illustrations of key concepts, such as the times of day and ages of man, in the body of some chapters. Francesco seems to have only included these rare illustrative images within the chapter if the idea under discussion was particularly complex and warranted a more detailed explanation. In the accompanying text near the images of Hope and Innocence, for example, he states explicitly that the textual explanation will not be enough: the images complement and complete the reading process. ${ }^{18}$

The Reggimento, on the other hand, might seem at first glance to be designed for an exclusively female readership, although as will be discussed shortly, this assumption must be challenged. The Reggimento is written in the volgare, with some sections in verse and some in prose, making it more approachable linguistically than the Documenti since the Latinate tradition pertained fairly exclusively to men. ${ }^{19}$ The textual 


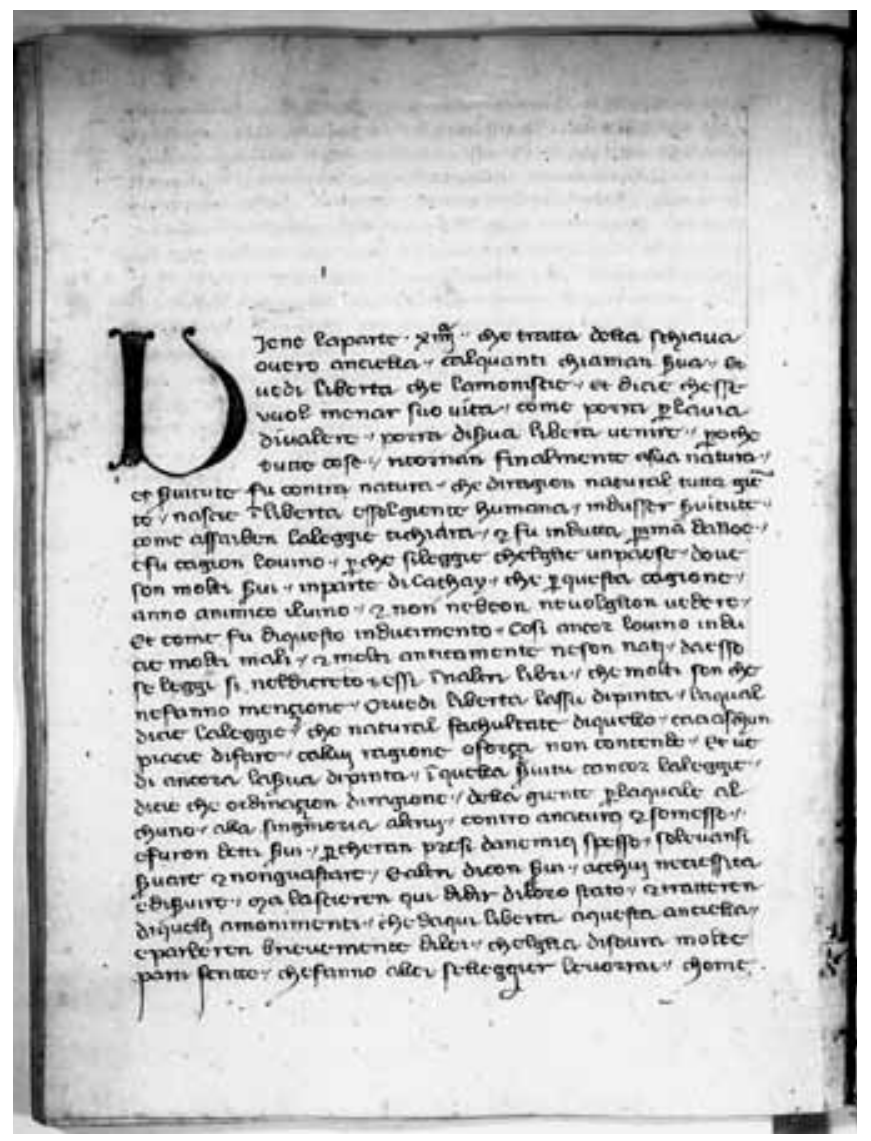

Figure 2. Francesco da Barberino, Reggimento e costume di donna, Biblioteca Apostolica Vaticana, Barb. lat. 440I, f. 63v. Reproduced with permission.

component is much more straightforward, with no wrapping of texts within each other on a page; rather, the different genres of text follow each other in straightforward linear fashion. The one extant and complete fourteenth-century manuscript of the Reggimento, now housed in the Biblioteca Apostolica Vaticana (Barb. lat. 4001), has blank spaces provided for illustrations, usually functioning as pictorial headings to chapters, although these were never completed, as we can see from figure 2.20 The author apparently intended to use similar, if not identical images, in several sections of each conduct book; for instance, Justice would have been featured in both. The composition of the two works were thus inextricably linked in the author's mind. Francesco tells us that he began his project in Florence with the composition of the text of the Reggimento but had to abandon the notebooks when he was forced into exile, and then travelled in northern Italy and throughout France. ${ }^{21} \mathrm{He}$ commenced work on the Documenti instead, and, a little later, resumed the project of writing for women, which was completed around 1318 or 1320.22 Sansone argues that we also have a possible first redaction of his work surviving in one fourteenth-century manuscript now in Rome, although others believe the text is only an extract from the original version. It is clear that Francesco developed both projects in his mind over time, based on the close interconnections found in the two texts. 23

In the Documenti, Francesco promotes the importance of grace, gratitude, and charitable love to his readers, indicating that love begins with sight and sensory experience but then develops as we progress through life stages and events, as we develop progressively more complex forms of understanding, including reasoning and spiritual revelation. He conveys his message through the appearances of a set of twelve allegorical personages who guide the reader in the acquisition of knowledge of the diverse forms of love. Each personage shapes the material in their respective chapter, in the following order: Docilitas (Sweetness), Industria (Industry), Constantia (Constancy), Discretio (Discretion), Patientia (Patience), Spes (Hope), Prudentia (Prudence), Gloria (Glory), Justitia (Justice), Innocentia (Innocence), Gratitudo (Gratitude), ending with Eternitas (Eternal Love). ${ }^{24}$ This text presents the journey of knowledge shaped by a concept of love that he connected to developing nobility of the soul, a topic that had occupied the contemporary authors Guido Guinizzelli and Dante. Eleonora Stoppino's recent study of Francesco's texts stresses that the Documenti d'amore offers advice on how to lead an honest and virtuous life. 25 Given the fact that it is written in Latin and volgare, its intended audience is more specialized than the Reggimento in terms of the literacy levels of its readers.

In the Reggimento, Francesco's muse, Madonna-who resembles the Virgin Mary but is most probably Divine Intelligence-requests that he write a book of conduct for women. She, together with a variety of personified virtues, such as Onestate and Eloquenzia (Honesty and Eloquence), Piatate and Cortesia (Piety and Courtesy), guide the author in the writing of the book. Over the course of twenty chapters, the reader is introduced to, in the following order: Innocenzia (Innocence), Verginità (Virginity), Pazienza (Patience), Speranza (Hope), Castitate (Chastity), Costanza (Constancy), Continenza I (Continence), Continenza II (Continence), Religione (Religion), Fortezza (Fortitude), Netta Fede (Pure Faith), Lealtade (Loyalty), Sottigliezza (Subtlety), Libertà (Liberty), Conduct for Women with a Trade, Prudenzia (Prudence), Compassione (Compassion), Industria (Industry), and Iustizia (Justice). Chapter twenty presents the book's triumphant conclusion, which offers a vivid description of a magnificent procession featuring a number of important allegorical ladies, including his Madonna. Each allegorical figure presides over a particular stage in a woman's life; the book is also important for its emphasis on rules of behaviour for different classes of women within society. 26 
Like many late medieval authors, Francesco understood the role of sensory perception as the principal means for his readers of the Reggimento to acquire higher forms of knowledge. The recent scholarship on memorial traditions stresses the importance of the role of vivid, visual imagines agentes and synaesthetic experience to animate the act of reading, to ensure a decisive impact on a reader's intentiones, or responses. ${ }^{27}$ Francesco creates vivacious verbal pictures, which are highly visual and synaesthetic, to stimulate the responses of his readers in both his books. ${ }^{28}$

As noted above, we are only able to study his use of both visual and verbal imagery to achieve this goal in the two fourteenth-century manuscripts of the Documenti, Barb. lat. 4077 and Barb. lat. 4076 in the Vatican library, given that copies of the Reggimento are unadorned. ${ }^{29}$ A number of scholars, especially Daniela Goldin, Eva Frojmovic, and Robyn Frechet, have advanced our understanding of the author's interest in manipulating the strong interplay of the visual and the verbal in these two extant illustrated manuscripts of the Documenti. The blank spaces on some of the pages of Barb. lat. 4001, the manuscript of the Reggimento, are tantalizingly empty as we try to supply the missing imagery in our mind's eye. 30 One distinctive feature of the Reggimento is the many verbal images Francesco provides of his struggle to write the book: these scenes rely on his description of his inner state-he is tired of writing, or filled with fear; he desires his Madonna, he is rewarded with some form of vision of her. As Lilianne Dulac notes, it is as if the book is being written before our very eyes: we are constantly made aware of the author's presence in the text, as we follow his body moving through space, or gain insight into his emotional world, especially in relation to the act of writing his text. 31

The author also appeals to the reader's sense of space, and many of the scenes of this quest take place in an urban environment. Contemporary readers could imagine the author's quest taking place in spaces that resembled the daily world of a typical late medieval European city or town. Since Francesco refers at times to noble ladies and social structures in late medieval France, scholars believe that he was writing for a pan-European audience, not just for his fellow countrymen and women.

Francesco uses allegory, a style of writing and mental mode greatly loved by many medieval and early modern thinkers, as one key strand in his writing. This form of writing offers readers complicated puzzles to work out in terms of levels of understanding, in the form of a series of passages that must be read in line with ethical traditions of reading and writing. According to Mary Carruthers, such allegorical puzzles are both anxiety producing and stimulating: the goal of reading requires that the reader find the right links to gather the clues into a significant chain of meaning. ${ }^{32}$ The prologue to the Reggimento, for instance, states explicitly: e ponetevi a cura ché in diverse parti del libro voi udirete parlar la detta donna sicché se voi sarete accorte persone e usate d'udire parlare così gentilemente porrave forse essere ch'avereste grazia da Dio di conoscere chi è questa donna che ci apar così chiusa 33 (and take note that in different parts of this book you will hear the said lady speak and if you are smart [or shrewd] people and used to hearing this kind of speech, it may be that you have [felt] the grace of God to understand this lady who appears here in a closed form).

The author makes no promises that his message will be received by all, and he steadfastly refuses to disclose the identity of his mysterious lady-love. There are many clues throughout indicating that Francesco expected his readers to work at the text and extract an important chain of meanings as they read from beginning to end.

Before considering the specific nature of these active, "speaking pictures" in the Reggimento, it is important to summarize Francesco's contribution to Italian literature at a pivotal moment in its history. There is no denying that the long and complicated Latin glosses surrounding his poetry in the Documenti, and the loose sense of narrative structure overall, would not have been easily comprehended by most readers of the period. However, despite lingering doubts about the artistic merits of his writing, there has been a steady stream of dedicated scholars over the centuries who have recognized his unique literary voice. In his study of 1883 , Antoine Thomas indicated the extraordinary depth of Francesco's knowledge of Provençal troubadour poetry. ${ }^{34}$ More recently, we have become aware of the wealth of his knowledge of the writing of Alan of Lilles, William of Conches, and Vincent of Beauvais. 35 Catherine Guimbard's articles on Francesco demonstrate his importance as a writer who addressed the changing political and social terrain of Florence during the period of the Ordinamenti di Giustizia of 1293, as well as several decades later, upon his return from political exile to Florence in 1315.36 Our author is therefore a very learned man, with modest literary talent. He did not form part of what Italian literary historiographers called the stilnovisti, Tuscan poets of the "sweet new style," a group that included Cina da Pistoia, Guido Cavalcanti, and Dante. As noted previously, he has attracted significant attention for his contribution to the development of the tradition of the novella in the period before Boccaccio.

Yet as Carruthers reminds us, authors like Francesco of didactic, vernacular compilations and florilegia provided their audiences with distinctive (but not original) works, which were indicative of Italian and French pre-humanist concerns during the thirteenth and fourteenth centuries. 37 Authors such as Brunetto Latini, Bono Giambono, Ser Zucchero Bencivenni, and Francesco da Barberino wrote with the aim of shaping the moral and ethical character of the laity, while at the same time 
providing an occasion for their own meditative, memorial acts of composition. 38 For instance, Bono Giambono, in his vernacular translation of the ancient memorial treatise Rhetorica ad Herennium, advised writers to make use of aural-visual synaesthesia, suggesting that images should speak. 39 The cultivation of the art of memory by these Tuscan authors encouraged and inspired the creation of visual-verbal imagery in works of art and literature. Francesco da Barberino's writings reveal the influence of these ideas, and his connection with this important group of thinkers. As Yates and Carruthers make clear, the memory arts do pertain in large measure to the formation of the morality of the person, and, I would add, this was related to learning how to read, think, and interpret. 40

Francesco makes use of three main textual strategies in the Reggimento. The first, and perhaps most intriguing strategy because of the interpretive puzzle it presents, is that of allegorical writing, which includes the story of the author's quest for Madonna, presented as a series of tableaux mouvants, or moving pictures. The end result is the reader's greater understanding of the nature of his Madonna. This strategy also includes the series of meetings between allegorical women who instruct their charges, as in the example of Innocence who advises the young girl in chapter one (Parte Prima). In the illustrated manuscripts of the Documenti d'amore, each one of the personified virtues, presented as a female figure, is displayed in a type of architectural frame or is enthroned and centered on the page; the images seem to speak directly to the reader, connecting the words they are reading to their summation in pictorial form on the page. As MacLaren states, the textual columns on the page "reinforce the presence of the figures, and...imply that the personification above is the embodiment of the text below." 41

Francesco also included a body of didactic teaching, which is presented throughout, with quotations from learned authorities such as Hippocrates or Galen on pertinent topics such as pregnancy, breast-feeding, habits of dress, and so on. The third strand in the writing is the more narrative material, which weaves together maxims, exempla, novelle, and anecdotes, ranging in time from antiquity to the fourteenth century; a large part of this material is based on stories taken from courtly literature. ${ }^{42}$ There is only space here to consider the allegorical strand of his work, although a fuller study of the interweaving of the different kinds of writing here-the exempla, novelle, didactic prose-is obviously necessary to understand the many ways that the author seeks to shape his readers' responses to his ideas of moral formation.

Francesco made allowances in the Reggimento for all sorts of social classes of readers, as in chapters eleven to fifteen of his book, which were written for servants and other females " $\mathrm{di}$ commune stato" (commoners). These chapters are written in a very straightforward fashion, and they do not contain any al- legorical passages, presumably because he assumed this kind of reader would not have sufficient training in this mode of reading. The manuscript defines conduct for women of all stations: he discusses the smallest details-how to smile so as not to show too many teeth-or he offers proscriptive examples, such as the tale of a potential bride who lost her lover to a woman of a lower social rank than her, simply because she showed too much leg while dancing. 43 Servants may have responded to the work, less in terms of gender roles (to be discussed below) than in terms of wishing to act less common, more like the noble ladies described so convincingly in the allegorical sections or in the vivid, didatic novelle. Whatever the social situation and whoever the reader, the book repeatedly stresses the value of pursuing self-control, of behaving in the best manner possible.

No scholar has to date considered his texts in terms of how they would impact on gendered readers. Of course, it is notoriously difficult to construe medieval attitudes to reading responses to any text. We would do well to remember the cautionary words by Jocelyn Wogan-Browne in relation to women's responses to the early thirteenth-century Guide for Anchoresses (Ancrene Wisse): she reminds us that "reading is an uncontainable as well as a highly scripted activity." 44 So much of what Francesco recommends is the acquisition of the ideals of selfcontrol, denial of the self, and the restriction of sexual impulses, encouraging his readers to seek out the compensation of a transcendental search for knowledge.

The Reggimento is a book of conduct written for women by a man, with the usual prescriptive patterns of behaviour for females. This seems to be the potentially dominant message- - that is, if we privilege a straightforward reading of the text itself, as well as consider the implied authorial intentions. Like other works in this genre of literature, Francesco's conduct books were intended to play an ideological role in the process of bourgeois self-definition, which obviously plays into gendered categories of appropriate behaviour for men and women. Guimbard, for instance, argues that his texts present a set of values that endorse worldly and material success in a late medieval urban context. ${ }^{45}$ As Roberta Krueger states, in a general comment about how authors of conduct books imposed their authority on women readers,

It is hardly necessary to emphasize the masculine bias of such a cultural construction of femininity.... The speaker who instructs is imbued with the authority and power that accrues to him because of his sex; the female recipient of the lesson is subordinate to the speaker by virtue of her non-authority. 46

But was Francesco's text only offering a top-down mediation of masculinist authority to his readers?

In fact, there are important clues throughout Francesco's text itself suggesting that the book was intended both for male and female readers, within the context of the family, and this 
fact allows us to probe more deeply into how gender would shape reader response. Francesco addresses readers directly throughout the book, as in this example: "Ma pertanto che gli legitori e le donne che legeranno vorranno tal fiata inducer le sue figlie a bella costumanza, per essemplo porete legere qui una legiadria e bella novella." 47 (But perchance both those [male] readers, and the women who will be reading, will want to induce good manners in their children, [in this case] you will be able to read here a lovely and beautiful story.) He then proceeds to tell an engaging novella to capture the flagging attention of his imagined reading community. Francesco's reference to both male and female readers acknowledges possible gender divisions in his authorial audience, raising interesting questions of how gendered readers made sense of a work like this: Did women read the allegorical love quest found in the Reggimento "like a man"? How did the author construe desire and pleasure for this varied audience? Were readers able to resist the authoritative voice used to convey social and moral teachings? Finally, given the important recent scholarship addressing heteronormativity and its constraints, should this work be read in exclusively heterosexual terms?

As Krueger points out in relation to the late medieval didactic poetry of Robert de Blois, the very insistence of male authors on the containment of female sexuality "betrays a profound anxiety about a masculine authority that must be so imposed." 48 There are elements of power and pleasure at work here in Francesco's work: the moralist seems to betray both anxiety about female sexuality, while simultaneously giving voice to his own desire-past or present-for the female body, even if it is (ostensibly) a spiritualized body of his Madonna. ${ }^{49}$ This is evident in his attention to describing parts of the female body with almost fetishistic delight, while at the same time urging his readers to seek the higher spiritual meaning of his text, and prescribing chaste, decorous behaviour at every turn. Following this line of analysis, his sense of sexual identities seem to overlap, to slip between categories, and we can postulate a complex gendered dynamic taking place between the reader and the text, especially the implied female reader. While some readers might have been complicitous with the erotic pleasures of his text, others may have questioned it; this hinges on the idea of learning to read on different levels, from the literal, mundane plane to the spiritual realm. We should note that the interplay between the different types of writings, exempla, novelle, and pious anecdotes, helps to disrupt the narrative tension of the author's love quest, adding additional layering to the process of reading, a dynamic that cannot be explored fully here.

Scholars like Felicity Riddy and Kathleen Ashley stress that we must move beyond simplistic explications of conduct books regarding the acquisition of gender or class roles, to consider how these texts might have produced household identities and more specifically, where there is sufficient evidence-family identities. As Ashley notes, the marginalia in manuscript copies of the didactic Miroir des bonnes femmes indicates that men, women, and children possessed and read conduct books, thereby disrupting "any simple binary system that separates male from female reading." 50 The single extant fourteenth-century manuscript copy of the Reggimento does not reveal a similar use of the margins to record events in a family's identity—as stated, they are blank-nor, for that matter, is this function in any way apparent in the two manuscripts of the Documenti. Nevertheless, the recent scholarship on the complex roles played by conduct literature in late medieval society urges us to be cautious in how we construe medieval readership responses: in sum, we must not assume a simple binary pattern of male versus female readers for his texts.

A reminder that books like this worked to construct the identity of a household may help us understand how women and men would have experienced the male desire of Francesco for the object of his quest in rich and varied ways, with much slippage in gender roles-a phenomenon evident in late medieval spiritual writing, or, as found recently by Jennifer Rondeau, occurred in the verses of Italian confraternity laude, or songs of praise.51 "Reading like a man" would make sense as part of the pattern of communal reading led by the paterfamilias, perhaps with all the members of the household present, including servants, as a performative experience. 52 For instance, scholars have noted the strongly Marian language Francesco used to describe his Madonna, as well as the importance of his devoted loveservice to her. $53 \mathrm{~A}$ female reader might have imagined herself as Madonna, object of a love-quest, or she might have followed the desiring subjectivity of the male author. The men of the household had equally important reasons to value the promise of social advancement of their family members, and women in particular, through the acquisition of proper modes of conduct, especially the lessons of love-service presented by Francesco.

Karma Lochrie's work challenging traditional heterosexist assumptions in our scholarship on late medieval women offers a further note of caution. ${ }^{54}$ She reminds us,

\section{In Bynum's work, and in most medieval scholarship, female mystical desire signifies only when it is heterosexual, when it confirms the masculine conventions of mysticism....From Hadewijch's fierce inversion of the courtly love tropes of mys- tical desire to Catherine of Siena's erotic coarticulation of the erotic and the sexual, female mystical discourse confounds gender and the heteronormative categories it inhabits, queer- ing them, causing them to lapse, balk and swerve. 55}

A similar possibility exists for the queering of female reader responses to the writing of Francesco da Barberino, although I would not want to limit any reader's response to such a complex 
text. Instead, I would argue for a range of different responses and possibilities within each reader as they experience the text, whether they are actually reading or hearing it. This greater openness and mutability offers us the capacity to imagine individuals who were capable of contesting sexual and gender codes, for "transgressive reinscriptions," as Lochrie states, of the codes of conduct. 56 With this framework in mind, we may now encounter the text itself, particularly its allegorical thread and the use of verbal and visual images, to gauge some of the possible responses for readers.

As stated above, one of the keys to acquiring a spiritualized type of knowledge through reading is learning how to read "properly," how to grapple with the author's allegorical puzzle. As Dulac notes, Madonna is an allegorical figure who, especially at the beginning of the book, is at once present and absent, interacting briefly with our author without fully revealing herself. 57 Then, as we progress through the book, from prologue to chapters two, four, six, nine, sixteen and twenty, we are offered more and more information on the physical nature and inner qualities of Madonna, until we experience the epiphanic presence of the Madonna and her virtuous ladies in the procession described in chapter twenty; Francesco relied on the capacity of his words and images to make the work memorable. Finally, the author receives his reward, a precious jewel from her crown, and the book comes to an end. The reader is aware, as we progress, of the author's various trials and tribulations, the setbacks and obstacles to his understanding-but he does become increasingly worthy of receiving a fuller vision of his lady, mimicking the kind of journey that a knowledgeable reader would also undergo.

In the Proemio, or prologue, the action unfolds mostly as a series of spoken parts by the various allegorical personages: Madonna, Honesty, Industry, Eloquence, Piety, and Courtesy. But before their humble servant, Francesco, will accept the task of writing the book of conduct for women, he wonders why Madonna is hidden from his view. She replies, " $[\mathrm{N}]$ on voglio esser(e) conosciuta e ben ti basta l'odor che ti spando e lo sprendor che ti raggia nel viso."58 (I do not wish to be known, and the odour that I exude and the splendour that is reflected on you from my face is enough for you.) She is described as a mirror in which she and her ladies are reflected, and from which others may take instruction. 59 From the very start, it seems, we are drawn into the author's search to achieve clear vision and understanding. The prologue ends with a listing of the contents of the twenty chapters, and the invocation for his readers to search for the hidden meaning in his text.

In chapter two the author discusses the allegorical figure of Virginity, in the presence of a young maiden who requires instruction in the time leading up to the marriage ceremony. She must remain with her mother, or other worthy female companions: if she gets a little bored, he suggests, she might try learning some songs. ${ }^{60}$ As happens elsewhere in the allegorical sections of the book, Francesco writes as if he is suddenly tired of writing - he needs to see his Madonna: he will take strength from being in her presence. He then enters a garden where she is resting. He begs her again to reveal herself to him, but is rebuffed. She still does not wish to be known, although she will allow him access from time-to-time, grace permitting. He is then dismissed because, we are told, Honesty is asking her to return to her chamber. ${ }^{61}$

In chapter four, which is dedicated to the virtue of Hope, the author provides advice for the young woman who has passed the marriageable age and who fears that she will not receive any offers of marriage. First, Francesco provides a brief introduction to Hope, which, in his view, is actually better expressed as the idea of trust. The personified virtue of Hope claims that her power is derived from God, and she speaks to the young woman through God; she asks the young women to stay by her side. Suddenly, Francesco's authorial voice asserts itself again: he is tired and filled with a strong desire to see his lady who is the "reason for this work," as expressed in the phrase "cagion di tutto esto lavoro." 62 Unexpectedly in terms of narrative progression, he addresses a group of women who are out walking to a festive celebration. He asks them if they have seen a lady who has no name, who reveals herself to those who are wise and know how to recognize her speech and her visage. They reply that they have seen such as a lady, who was seated in a garden:

\footnotetext{
$[\mathrm{N}]$ oi passando qua per un giardino vedemo star a piè d'una fontana una solenne donna chiusa in velo e non vedemo persona con lei. Un picciol cuciolino avia da piedi;... sue man lavava alla spina del fonte. 63 (We, passing by a garden near here, saw, resting at the foot of a fountain, a solemn lady enclosed in a veil, who was alone....She had a little dog at her feet...she was washing her hands in the fountain.)
}

The next line focuses in particular on her hands, which were "bianche...e lunghe e sprendienti" (white...long and splendid), her arms and shoulders are "amorose," lovable. ${ }^{64}$ She wears silk slippers adorned with precious jewels. The visual description is interrupted by the introduction of the element of sound. The ladies are amazed at her beauty, and they make a noise: at this, the lady turns her eyes to the group, and her audience falls to the ground, overcome by her splendour and wonder. The lady flees, but in fleeing she exudes an odour, prompting one of her onlookers to pronounce, "Questo è 'l Paradiso ché donna piena di tanto valore non sarie venuta a dimorare in terra."65 (This is Paradise, a lady so worthy could not have come to live on the earth.) Francesco, speaking through the voices of this group of ladies, presents us with a partial vision of what this attractive lady looks like, and notes the beauty of her sacred scent. 
Eventually, the ladies direct Francesco toward a street that lies off an alleyway; there he will find a palace in an opening, where he must go and call on the lady. Having arrived at the palace, he first encounters Cautela (Caution), who blocks his access to the lady until Cortesia (Courtesy) intervenes on his behalf. When he is finally brought before Madonna, Piagere (Pleasure) and Dolcezza (Sweetness) bind him with Madonna's veil. Madonna asks her companions to tie him even tighter. Her face is veiled, and Francesco mentions that he can only see her eyes. The scene takes place in a beautiful room covered with paintings, and Madonna is seated on a large sapphire. 66

Francesco tells her that just a few days ago he had a vision, which is difficult to understand-perhaps she will be able to assist him in its interpretation. She asks him to recount the vision to the assembly. He states that he experienced an image of himself as a parrot, bound and held on a carpet in a large pavilion. The parrot has been brought before a lady who is seated on a sapphire, "una libera donna in veste onesta" (a free lady in honest raiment). The lady then binds the parrot with her garland, and he is caught and transformed into a viper (as he writes, "mi fe' legare e io divenni tiro"). ${ }^{67}$ Madonna wonders: Is she the same lady as shown in the vision, and how or why was he caught in this way? No conclusive answer emerges in the text, but Francesco then suggests that some people might wish to flee from the lady-these will be individuals who are unfaithful to her (the implication is that others will not be so afraid and will be brought before her). Her effect on humans is very similar to the workings of the God of Love discussed in the Documenti. 68 Next, she orders him to return to his first state, that of being a man rather than a bird or a viper; he will be able to resume his true nature if he is not afraid.

It would seem then, from these rather oblique and complicated passages, that the rewards for being love-struck with desire for this elevated lady are higher forms of understanding and a state of contemplative bliss, but only those who leave fear behind will experience these rewards. Suddenly, in an apparent moment of petulance — ever the courtly lady—Madonna orders him to leave. He may retain the veil and the garland. He takes his leave, content to carry on his task now that he has glimpsed her, now that he has these tokens to reassure him, even though they have parted company. For those readers who have identified with the author's quest, the author seems to promise a series of small rewards and compensation for those who progress through the book, attempting to interpret meaning as they emerge from his quest to know his lady.

Francesco has used a number of common iconographic motifs from scripture and courtly love traditions. He refers several times to a garden, alluding presumably to the one in the Song of Songs, the paradisiacal spot, the locus amoenus. The group of passing ladies has been privileged to catch a glimpse of Madonna's veiled face, her splendid hands, her feet. There is an eroticized quality in the way the ladies describe her body. When Francesco arrives in her audience chamber, he is bound with her veil and garland-common literary conventions from the romance tradition. ${ }^{69}$ Yet as happened within this literary tradition, the object of his desire is cast in terms of fleeting encounters; she remains an object of shifting desire.

The allegory becomes more elaborate in chapter six. This chapter is devoted to the widow, who is comforted by Constancy. The author has learned to form an image of Madonna in his mind's eye (as he writes, "cogli occhi della mente mia"), 70 which forms part of the tradition of memorial recollection. He is accompanied by two virtuous ladies, Piety and Courtesy, who help him to endure many trials: he enters a dark wood but they tell him to not fear the "passi dubiosi," the fearful places. He then has to pass through fire, all the while shielding his eyes. We are told also that these ladies have no need for food, indicative of their superhuman status. ${ }^{71} \mathrm{He}$ traverses mountains covered with snow and intensely cold; he crosses rivers, enduring hardship for two hundred days. Once he has reached his goal, Madonna commands him to look at her; she points out that her faithful little dog always accompanies her. ${ }^{72}$ Francesco, in turn, offers a more detailed reading of her body than we have encountered to date in the text: her breasts that nourish, her voice that calms him, her aura that cleanses his heart. From her glorious hair to the perfection of her lips, hands, and feet, she was clearly created in the mind of God, before all other creatures. ${ }^{73}$ Both here and in the Documenti, Francesco makes use of the traditional language of Marian devotion to offer praises to his lady. She asks him about the progress of the book that he is writing, and then he is dismissed, but told to return tomorrow to a nearby chapel at nones, that is, around three o'clock. ${ }^{74}$

Chapter nine is devoted to Religion, particularly to the religious woman living in a monastery, or in perpetual enclosure. Almost at the very end of the chapter, he grows tired again of writing the book. He first asks a pilgrim, a cavaliere, or knight, if he has seen his lady. The knight has seen her at the top of a distant mountain: Francesco must look for her at the entrance to a large white pavilion. ${ }^{75}$ The mountain seems impassable, with its many rocks, crevices, and boulders, but Francesco is carried to his goal on the back of a female bear. ${ }^{76} \mathrm{He}$ receives a scolding from Madonna, who is growing impatient with him and wants him to finish the book. She offers him the support of Preseveranza (Perseverance) that he might complete his task. This time, however, when he asks for a token from her, she refuses. 77 The chapter ends with Francesco addressing his readers directly, telling them to remember the lady and the company she keeps.

In chapter sixteen, which is devoted to Prudence and comprised of many moralistic comments about women, Francesco 
sees Madonna again. Since this chapter discusses how women adorn themselves in an appropriate manner, it seems fitting that he should profit from the unexpected vision of Madonna who passes by in her carriage. This time, Penitenzia (Penitence) calms his ever-present fears and prompts him to speak to Madonna directly. He comments on Madonna's beauty, noting that a star obscures her face: if only she would remove it, he might see her better. Of course, she refuses and they part company, but not before she has urged him to go with Penitence. He has been humbled, he says, and these ladies have returned him to the "ritta via," or correct path. 78 Suddenly, the reader is returned to the mundane world of hair care and dental treatments. 79

The book concludes with the grand procession of $\mathrm{Ma}$ donna and her court, with the last chapter being presided over by the allegorical figure of Conclusion. Eloquence agrees to assist him in the task of describing the scene before his eyes. She helps him to name the different personages riding by: Onestà (Honesty), Prudenzia (Prudence), Providenzia (Providence), Circonspectione (Circumspection), Iustizia (Justice), and so on. $\mathrm{He}$ is brought before Intelleto (Intellect), who ushers him into the presence of Madonna. The penultimate section in chapter twenty is a lengthy prayer praising Madonna, which is also heavily reliant on Marian imagery. At last he receives a reward for all his work; the book is complete and Madonna presents him with a splendid jewel from her crown. She urges Francesco to look more closely at the jewel, to see an image carved upon its surface:

E guarda, nella parte ch'é nel mezzo, quella figura che scolpita v'é entro; poi leggi il primo cerchio verso l'mezzo, poi lo sicondo, poi 'l terzo e 'l quarto, e dà volta alla pietra e leggi il quinto, poi ti rinmembra di che vuo' sapere. 80 (And look at the part in the centre, at the figure which is sculpted there; then read the first circle towards the middle, then the second, then the third and the fourth, and then turn the stone and read the fifth, then you can remember that which you want to know.)

This is clearly a mnemonic device designed to act as a memorable image for the recollection of the various stages of remembrance. The description may seem a little vague, but he/we have in fact seen Madonna and learned a little more about her over five appearances. Our view of her in the final chapter is the most complete, and we are encouraged to try to remember her manifold aspects in a series of progressive steps. Like the picture poems by Theodulph of Orleans, or Hugh of St. Victor's image of Noah's ark, which rely on images of maps or trees to stimulate memorial reflections and meditative composition in the minds of listeners or readers, Francesco's description of the jewel is a mnemonic prompt for readers of his text. ${ }^{81}$ His invitation to use the picture is clear, suggesting that he considered his jewel- picture, or even the earlier pictures of Madonna, to be tools for further meditation and interpretation, not just a fixed illustration of concepts. With some application, we can form a chain of vivid imagines, which are fleshed out fully, one might even say, in vivid synaesthetic detail.

Our understanding of negotiating text and image is complicated further by suggesting that the role of gender and sexuality in terms of the readership of this memorable conduct book must also be considered. This essay has suggested that analyzing gendered readership in the conduct books by Francesco da Barberino offers modern-day readers an important avenue to better understand the complex dynamic of reading processes: in particular, we need to do more research on how reading could shape social, religious, moral, and gendered identities in late medieval European society. The Reggimento and Documenti d'amore did, no doubt, serve to reinforce dominant cultural definitions of masculinity and femininity. But texts such as this cannot be read along simplistic lines of male/female response. The subtle play of power, pleasure, and desire within the Reggimento, and the troubling notion of women reading "like a man," anxious to know the body and spirit of Madonna (Divine Intelligence), or the possibility of the arousal of same-sex desire, indicates that the effect of courtesy manuals upon the reader was more complicated than we had previously imagined. We must not assume that readers necessarily adhered to rigid patterns of sexual conformity. Their response may, in fact, have been troubled, caught as they were between Francesco's overt advocacy of female chastity, and his construction of the female body as a site of desire. Needless to say, we must remember that his texts do not represent the reality of life for late medieval men and women; rather, this author offers us an idealized view of how he wishes social life could be ordered: these are his dreams of the highest standards of conduct.

Above all, his writings belong to a pan-European project of long duration that continues on into the early modern period, a project that is being increasingly explored by scholars examining literacy and identity-formation. Francesco's texts expressed ways to strive towards the goal of achieving a good life in heaven and on earth, by shaping body, mind, and soul using vivid words and pictures. ${ }^{82}$ As Karl Enenkel states,

\footnotetext{
In the late medieval and early modern period, the reception of texts was far from a simple and obvious business... It was a complex and demanding process that required...great concentration...advanced skills in the techniques of mnemonics (memoria), meditatio, and interpretatio. 83
}

Francesco's exploitation of text and image in his writings places him firmly within a changing socio-cultural context that saw the expansion of literacy and the rising importance of self-formation for men and women alike. 


\section{Acknowledgements}

I am grateful for the support of SSHRC and the University of Victoria; this work would not have been possible without their financial aid. Earlier versions of this work have profited from the comments of Barbara Winters, Marla Steven, Erin Campbell, and Laura Maria Marchiori.

\section{Notes}

1 His life is discussed in A. Thomas, Francesco da Barberino et la littérature provençale en Italie au moyen âge (Paris, 1883).

2 For a recent discussion of this category of literature, see Medieval Conduct, ed. K. Ashley and R.L.A. Clark (Minnesota, 2001), ix-xx; and Medieval Conduct Literature. An Anthology of Vernacular Guides to Behaviour for Youths, with English translations, ed. Mark D. Johnston (Toronto, 2009).

3 R. Krueger, "Introduction," in Medieval Conduct Literature, ix.

4 K. Enenkel and W.S. Melion, eds., Meditatio-Refashioning the Self. Theory and Practice in Late Medieval and Early Modern Intellectual Culture (Leiden and Boston, 2011), 17.

5 V. Kolve, Telling Images. Chaucer and the Imagery of Narrative II (Stanford, 2009). See also New Approaches to Medieval Communication, ed. M. Mostert (Turnhout, 1999), for an important contribution to understanding literacy, orality, and the relationship to precise socio-cultural contexts.

6 Enenkel and Melion, Meditatio, 2.

7 As discussed fully in S. MacLaren, "Shaping the Self in the Image of Virtue: Francesco da Barberino's I Documenti d'Amore," in Image and Imagination of the Religious Self in Late Medieval and Early Modern Europe, ed. R. Falkenberg, W. Melion, and T. Richardson (Turnhout, 2007), 71-95.

8 L. Amtower, Engaging Words. The Culture of Reading in the Later Middle Ages (New York, 2000), 5.

9 Enenkel and Melion, Meditatio, 17.

10 Enenkel and Melion, Meditatio, 14.

11 The literature on the topic of gendered reading responses is extensive, but see, in particular, S. Feldman, What Does a Woman Want? Reading and Sexual Difference (Baltimore, 1993), for a key contribution to this field.

12 The literature on gender instability is vast, but see J. Butler, Gender Trouble: Feminism and the Subversion of Identity (New York, 1990).

13 See F. Quiviger, The Sensory World of Italian Renaissance Art (London, 2010); and Amtower, Engaging Words.

14 See I Documenti d'amore secondo i manoscritti originali, ed. F. Egidi, 4 vols. (Rome, 1905-27); Reggimento e costumi di donna, ed. G. Sansone (Florence, 1957), 2nd edition, 1990. Sansone's edition does not modernize the original vernacular. The criteria for a new edition of this text are presented in M.C. Panzera, "Per l'edizione critica dei 'Documenti d'amore' di Francesco da Barberino," Studi mediolatini e volgari 40 (1994): 91-118. For the most recent two-volume edition of the Documenti, see Francesco da Barberino. I documenti d'amore [Documenta Amoris] and Documenta amoris [Glossae], ed. M. Albertazzi (Lavis, 2008). Illustrations of the text are published by B. Degenhart and A. Schmitt, Corpus der italienischen Zeichnungen, 1300-1450, 4 vols. (Berlin, 1968), I, 1, pls. 48-65.

15 S. L'Engle and R. Gibbs, Illuminating the Law (London/Turnhout, 2001), 56, discuss this type of page layout for legal manuscripts. It is not surprising that Francesco chose this format for his texts since he trained as a notary and judge.

16 For an illustration of the page layout, see S. MacLaren, "Shaping the Self," figure 25, illustrating Docilitas.

17 See the recent discussion by R. Fréchet, "Lillustration didactique d'un auteur encyclopédiste-moraliste au début du XIVième siècle: Francesco da Barberino et ses Documenti d'amore," Ph.D. diss., Université des Sciences Humaines, Strasbourg, 1996. I am grateful to Robyn Frechet for her generosity in all matters, and access to her manuscript, which has been submitted for publication. Other important contributions are: A. Petrucci and F. Petrucci Nardelli, "Minima barberina. I. Note sugli autografi dei Documenti d'amore. II. L'Eternità Barberina. Dalla miniatura alla stampa," in Miscellanea di studi in onore di Aurelio Roncaglia a cinquantanni dalla sua laurea, 3 vols. (Modena, 1989), iii, 1005-14; P. Supino, "Per la tradizione manoscritta dei 'Documenti d'amore' di Francesco da Barberino," Studi medievali, 3 ser., 37, 2 (1996): 945-54.

18 MacLaren, "Shaping the self," 75.

19 For literacy among laywomen, especially in Italy, see D. Herlihy, "The Natural History of Medieval Women," in Natural History 87 (March 1978): 56-67; and "Family Solidarity in Medieval Italian History," in Economy, Society and Government: Essays in Honor of Robert J. Reynolds, ed. D. Herlihy et al. (Kent, Ohio, 1969), 173-84.

20 Sansone, Reggimento, pp. xvi-xxii, 229-307, discussed the other two surviving manuscripts and previous printed editions. One manuscript dates to the fourteenth century but is an incomplete preliminary version of the final text, which is housed in the Collegio Internazionale S. Alessio Falconieri O.S.M. in Rome, with a provisional shelf-mark that I have not verified further, and the seventeenth-century manuscript copying the full fourteenth-century text, housed in the Biblioteca Apostolica Vaticana, Capponiano 50.

21 See, in particular, G. Biscaro, "Francesco da Barberino al sequito di Corso Donati," Nuovi Studi Medievali 1 (1923): 255-62; C. Guimbard, "Recherches sur la vie publique de Francesco da Barberino," Revue des Études Italiennes 28, 1-2 (1982): 5-39; "Signifié e signifiant de l'itinéraire barberinien dans le Reggimento e costumi di donna de Francesco da Barberino," Lettere Italiane 41, 
1 (1989): 1-27; "Le Reggimento e costumi di donna de Francesco da Barberino: une oeuvre témoin," Revue des Études Italiennes 36, 1-4 (1990): 43-58; and "La motivation 'communale' du Reggimento e costumi di donna de Francesco da Barberino," Filiologica e critica 16, 2 (1991): 252-66.

22 For his biography, see E. Pasquini, "Francesco da Barberino," in Dizionario biografico degli Italiani 49 (Rome, 1997), 686-91.

23 See Reggimento, ed. Sansone, 229-37. This is the manuscript held in the library of the Collegio Internazionale di S. Alessio Falconieri, Rome, Alexianus I.3. It comes from the convent of San Marcello, Rome, according to Reggimento, ed. Sansone, 230; the relevant pages are ff.23ra-39ra. According to Pasquini, "Francesco da Barberino," 690, this work is an excerpt and not a first redaction.

24 See Documenti d'amore, ed. Egidi, iv, 102-29.

25 E. Stoppino, "The Italian Reggimento e costumi di donna (selections) and Documenti d'amore (selections) of Francesco da Barberino," in Medieval Conduct Literature, ed. Johnston, 127--189.

26 See Reggimento, ed. Sansone, 1-226, for the text. Chapter fifteen is the only one not headed by an allegorical personage: he presents short maxims for women in various trades, such as the barbiera (hairdresser), pollaiuola (poultry worker), or tessitrice (weaver or textile worker).

27 M. Carruthers, The Book of Memory (Cambridge, 1990), and The Craft of Thought (Cambridge, 1998). For a discussion of this phenomenon in literary practices in general, see E. Scarry, Dreaming the Book (Princeton, 1999).

28 Francesco may have based his visual orientation in part on the earlier poetic tradition of Fra Guittone d'Arezzo, who conceived of at least one of his works, a Trattato d'amore (a treatise of lyric poetry on love), as including an illustration that functioned like a gloss to the poem. H.W. Storey, Transcription and Visual Poetics in the Early Italian Lyric (New York, 1993), 171-89.

29 D. Goldin, "Testo e immagine nei Documenti d'amore di Francesco da Barberino," Quaderni d'italianistica I, 2 (1980): 125-38; E. Frojomovic, "Der Illustrationszyklus zu den 'Documenti d'amore' des Francesco da Barberino," Ph.D. diss., Ludwig-Maximilians Universitat zu München, 1993; Frechet, "Lillustration didactique." For an important general discussion of these issues, see M. Ciccuto, "Guinizzelli e Guittone, Barberino e Petrarca: le origini del libro volgare illustrato," Rivista di Storia della Miniatura 1-2 (1996-97): 77-87.

30 There is less focus on the sense of taste, although certain passages in the book do discuss correct approaches to food at the table and conduct during feasts. He also works with the sense of touch from time to time.

31 L. Dulac, "Mystical Inspiration and Political Knowledge: Advice to Widows from Francesco da Barberino and Christine de Pizan," in Upon My Husband's Death. Widows in the Literature and Histories of Medieval Europe, ed. L. Mirrer (Ann Arbor, 1992), 223-58, at 224 .
32 Carruthers, Craft of Thought, 166-67.

33 Reggimento, ed. Sansone, 7, lines 30-33. All translations are my own.

34 A. Thomas, Francesco da Barberino et la littérature provençale en Italie au Moyen Age (Paris, 1883).

35 G. Billanovich, M. Prandi, and C. Scarpati, "Lo 'Speculum' di Vincenzo di Beauvais e la letteratura italiana dell'età gotica," Italia medioevale e umanistica 19 (1976): 89-170.

36 Guimbard, 'Signifié et signifiant," 1-27; and "Le Reggimento e costumi di donna," 43-58. As discussed also by Frechet, "Lillustration didactique," introduction, typescript, n.p.

37 Carruthers, Book of Memory, 182-85.

38 See, for instance, the important study by J. Allen, The Ethical Poetic of the Later Middle Ages (Toronto, 1982); and the important discussion in Bono Giambono, Il Libro de'Vizi e delle Virtudi, ed. C. Segre (Turin, 1968), xiv-xxxv.

39 See M. Carruthers, "Italy, Ars Memorativa and Fame's House," Studies in the Age of Chaucer, Proceedings Series 2 (1986-87): 179-87; Carruthers, Book of Memory, 229-30.

40 F. Yates, The Art of Memory (Chicago, 1966), 88-90; and Carruthers, Book of Memory, 156-88.

41 MacLaren, "Shaping the Self," 80.

42 C. Cazale, "Le Reggimento e costumi di donna de Francesco da Barberino. Un miroir truqué," in Médiévales: langue, texte, historie 6 (1984): 69-84.

43 Reggimento, ed. Sansone, 11.

44 J. Wogan-Browne, "Chaste Bodies: Frames and Experiences," in Framing Medieval Bodies, ed. S. Kay and M. Rubin (Manchester, 1994), 33. Emphasis added.

45 See, for instance, F. Riddy, "Mother Knows Best: Reading Social Change in a Courtesy Text," Speculum 71 (January 1996): 66-86, at 69; and K. Ashley, "The Miroir des Bonnes Femmes," in Medieval Conduct, ed. Ashley, 86-105: the latter author examines the textual evidence that these manuscripts were used to record significant family events and document the lineage of the household. Guimbard, "La motivation 'communale," 252-66, discusses Francesco's focus on social concerns.

46 R. Krueger, Women Readers and the Ideology of Gender in Old French Verse Romance (Cambridge, 1993), 160.

47 Reggimento, ed. Sansone, 16, lines 34-36.

48 Krueger, Women Readers, 160-61.

49 Krueger, Women Readers, 161.

50 Ashley, "Miroir des bonnes femmes," 90.

51 As discussed by J.F. Rondeau, "Conducting Gender. Theories and Practice in Italian Confraternity Literature," in Medieval Conduct, ed. Ashley, 183-206. See also E. Petroff, Medieval Women's Visionary Literature (Oxford, 1986), 3-59, with important bibliography.

52 For the performative aspect of late medieval reading practices, see K. Kerby-Fulton and D. Despres, Iconography and the Professional Reader (Minneapolis and London, 1999), 5-14, 119-68. 
53 Dulac, "Mystical Knowledge," 224-25.

54 K. Lochrie, "Mystical Acts, Queer Tendencies," in Constructing Medieval Sexuality, ed. K. Lochrie, P. McCracken, and J. Schultz (Minnesota, 1997), 180-200.

55 Lochrie, "Mystical Acts," 195.

56 Lochrie, "Mystical Acts," 195.

57 Dulac, "Mystical Knowledge," 225.

58 Reggimento, ed. Sansone, 2, line 8.

59 Reggimento, ed. Sansone, 3, lines 38-40.

60 Reggimento, ed. Sansone, 20.

61 Reggimento, ed. Sansone, 21, lines 5-36.

62 Reggimento, ed. Sansone, 35, line 6.

63 Reggimento, ed. Sansone, 35, lines 32-38.

64 Reggimento, ed. Sansone, 35, lines 38-40.

65 Reggimento, ed. Sansone, 36, lines 9-11.

66 His work is clearly indebted to the didactic poem "L'Intelligenza," as discussed by M. Ciccuto, Il Restauro de 'L'Intelligenza' e altri studi dugenteschi (Pisa, 1985).

67 Reggimento, ed. Sansone, 39, line 11. According to Guimbard, "Signifié et signifiant," 17, this episode indicates the difficulties of overcoming one's bestial nature, although the author does triumph in the end.

68 As discussed by E. Jacobsen, "Francesco da Barberino. Man of Law and Servant of Love," parts I and II, in Analecta Romani Instituti Danici, part I: 15 (1986), 87-118, and part II: 16 (1987), 75-106. See also C. Franco, Arte e poesia nel Reggimento e costumi di donna di Francesco da Barberino (Ravenna, 1982), for the parallels between the two works.

69 For an evocative discussion of "love's gifts," see M. Camille, The Medieval Art of Love (New York, 1998), 50-71.

70 Reggimento, ed. Sansone, 100, line 14.

71 Reggimento, ed. Sansone, 101, lines 25-27, and 102, lines 2-4.

72 Reggimento, ed. Sansone, 103, lines 20-26.

73 Reggimento, ed. Sansone, 104, lines 14-40.

74 Reggimento, ed. Sansone, 106, line 23.

75 Reggimento, ed. Sansone, 138, lines 42-44.

76 The significance of this detail is discussed by Guimbard, "Signifié et signifiant,"17; and Frechet, "Lillustration didactique," typescript, introduction, who makes a convincing case for a connection between this image and Francesco's relationship to the bishop of Florence, Antonio degli Orsi.

77 Reggimento, ed. Sansone, 141, lines 3-17.

78 Reggimento, ed. Sansone, 201, lines 1-40.

79 Reggimento, ed. Sansone, 202-4.

80 Reggimento, ed. Sansone, 225, lines 22-27.

81 These imagines are discussed by Carruthers, Craft of Thought, 209-13, 243-46. See also Carruthers, "Italy, Ars Memorativa," 183-85, for a discussion of Dante's description of carved images and their relationship to medieval mnemonic traditions in Italy.
82 Medieval Conduct Literature, ed. Johnston, xxix.

83 Enenkel, "Meditative Frames as Reader's Guidance in Neo-Latin Texts," in Enenkel and Melion, Meditatio, 27. 